\title{
Courage and Conscience
}

Black and White Abolitionists in Boston

\section{Edited by Donald M. Jacobs \\ Foreword by John Hope Franklin}

Untll recently little was known of the contrtbuttons of African Americans in the antebellum abolltion movement. Massachusetts, having granted voting ights early on to black males, was a center of antislavery agitation. Courage and Consclence documents the black acttvism in 19th-century Boston that was critical to the success of the abolitionist cause.

Published for the Boston Athenzum by Indlana Unlversity Press 90 b\&w photos, cloth $\$ 39.95$ paper $\$ 19.95$

\section{The Way of the Cross Leads Home}

The Domestication of American Methodism

\section{A. Gregory Schneider}

"[An] Imaginattve, brtlliant, and profound case study of American Methodlsm. . . . Schnelder's readlng of Methodlst discourse provides a truly Innovattve way of thinking about nineteenthcentury American falth, gender, famlly, and culture."

-Donald G. Mathews

Thls richly detalled study of the rise of American Methodlsm and its social and cultural impact focuses on Methodlst rellglous practice.

Rellgion in North America

Avallable Aptl cloth $\$ 29.95$

\section{Santeria from Africa to the New World}

The Dead Sell Memories

\section{George Brandon}

"... a compelling and coherent descriptlon of the processual development of Santeria." -Karen McCarthy Brown

Brandon follows the path of this Yoruba rellglous tradition from Africa to Cuba to New York Oty. In following Santerta's historical and anthropological evolutlon, Brandon dlscusses broader questions of power, multiculturallsm and cultural change. Blacks in the Dlaspora Available June cloth $\$ 29.95$ 


\section{Spiritual Spectacles}

Vision and Image in Mid-

Nineteenth-Century Shakerism

\section{Sally M. Promey}

"Sally Promey's Inquiry ... crittcally engages current issues in the study of visual culture: what do Images do; how do they work; what needs do they fultill; just what is thelr 'power'? Her compelling case study jolns fundamental concerns of art historlans with those of students of rellgion and history ... By means of an exacting examination of Shaker drawings as the site of both expectatton and encounter, Promey successfully situates these Splitual Spectacles at the meeting point of the 'Inner' and the 'outer' eye." - Linda Seldel, author of Jan van Eyck's Amolfni Portralt: Stories of an Icon

"Promey has brought to her work an excellent sensituvity to the rellglous issues involved, keen sight and powers of observation, and a very creattve Interprettve framework." - -Stephen J. Steln, author of The Shaker Experience in America

\section{Rellgion in North America}

Avallable Aptl 5 color photos, 34 b \& w photos, cloth $\$ 35.00$

\section{Mother's First-Born Daughters} Early Shaker Writings on Women and Religion

\section{Edited by Jean M. Humez}

"Israel, you have begun to bear for other souls, and you must never give out, ttll the last soul is gathered in. When you get home, tell your father and stepmother that your mother is itsen from the dead." -from the book

A fascinatting Introduction to the world of the early Shakers, thls anthology documents the contributtons to Shaker rellglon made by women durlng its first seventy years. It gives a more accurate vislon of Shakerlsm and hlghllghts the ways In which gender can play an Important role in

the creatlon of a new rellglous insttutton. Rellgion in North America Avallable May cloth $\$ 39.95$ paper $\$ 17.50$

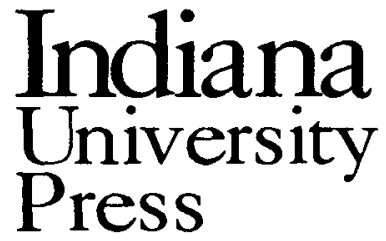

Bloomington, IN 47404

At bookstores or 1-800-842-6796

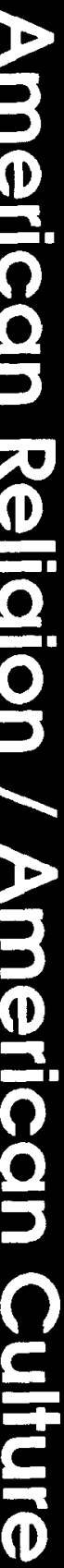




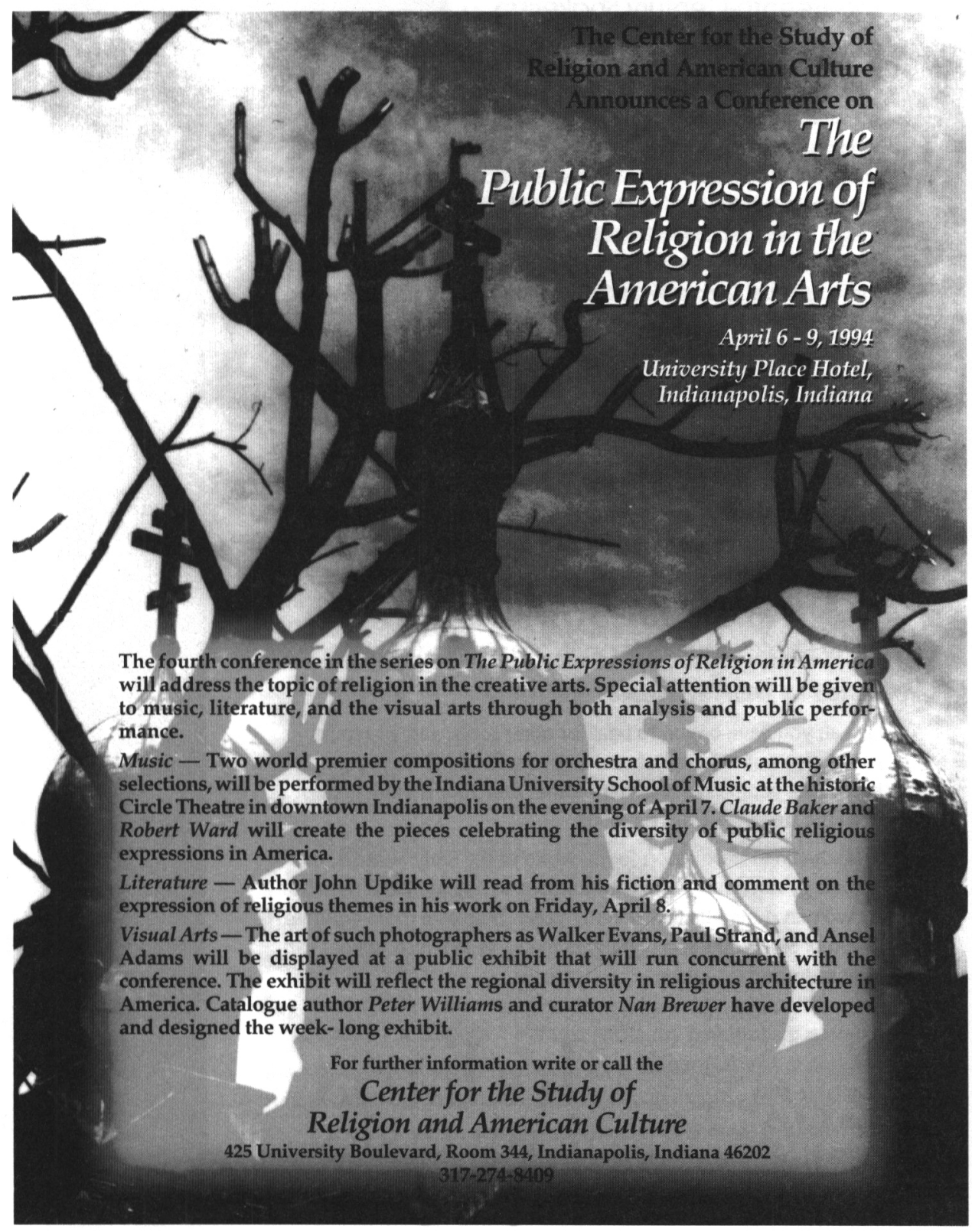




\title{
THE JOURNAL OF RELIGIOUS HISTORY
}

The journal publishes articles and reviews current work on the history of religion and on the relationship between religion and other aspects of human experience. It draws on work from as broad a field of interests as possible: ancient, medieval and modern (including, especially, Australasian) history. It is published twice yearly, in June and December.

1991 issues will include articles on

Witness and eleventh-century monastic revival

John Knox's vision for Scotland

Social reconstruction in seventeenth-century New England

South Australian churches and social issues, 1919-1939

1992 issues will include articles on

The Codex in early Jewish and Christian communities

Dean Inge and cultural crisis, 1899-1920

State, war, revolution and the German Evangelical Church,

1914-1918

Franciscan ideals and New Guinea realities, 1946-1951

Editor: A.E. Cahill

Editorial correspondence: History Department, University of Sydney, NSW Australia 2006

\author{
ANNUAL SUBSCRIPTIONS \\ Individuals: A\$38 (US\$40; UKf24) \\ Institutions: A\$70 (US\$72; UKf42)
}

Subscriptions should be sent to Journal of Religious History Treasurer, Department of History, University of Sydney, NSW Australia 2006 


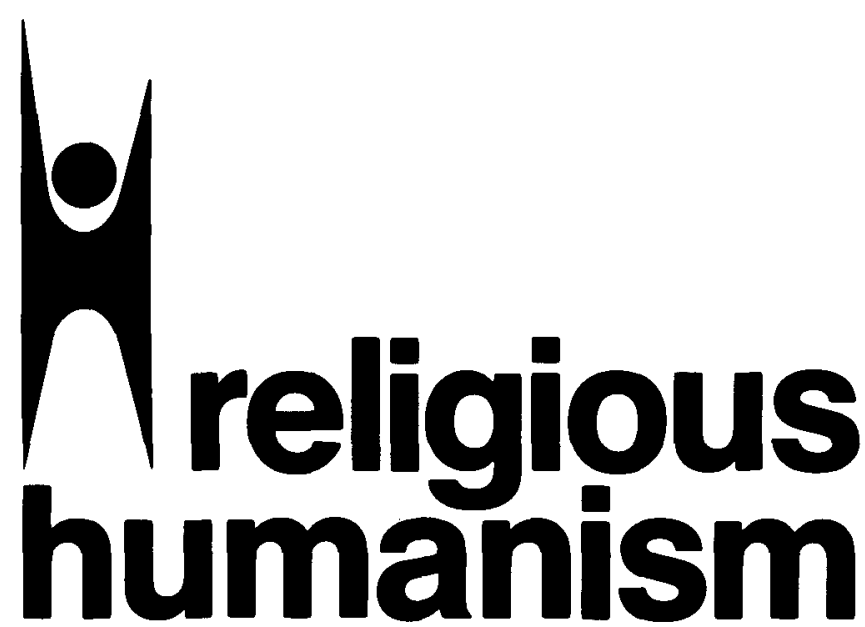

A Quarterly Journal Published by the Fellowship of Religious Humanists, Inc.

Examples of articles appearing in Religious Humanism include the following: Humanism: American Democratic Faith? . . . . . . . . . . Khoren Arisian Is the Negation of Christianity the Way to Its Renewal? . . . . . Thomas J.J. Altizer

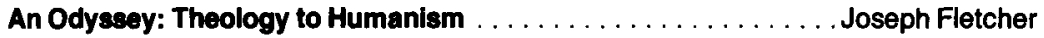
Can the Death of God Die? . . . . . . . . . . . . . . . . William Hamilton

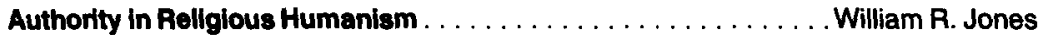
Humanism and Sexual Morality . . . . . . . . . . . . . . . Lester Kirkendall Is Anything Sacred? Christian Humanism and Christian Nihilism . . . . Don Cupitt If Humanism is a Rellgion . . . . . . . . . . . . . . . . . Sherwin Wine Ecumenical Humanism . . . . . . . . . . . . . . . . Archie Jahm South Place Ethical Society ....................... Blackham

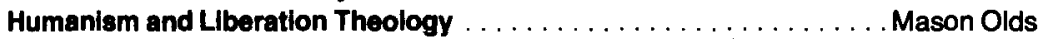
Theology of the Big Bang . . . . . . . . . . . . . . . . Ralph Alpher The Philosophy of Moral Freedom . . . . . . . . . . . . . Paul Kurtz Fellx Adler and the Free Religious Association . . . . . . . . Robert Hemstreet Humanism and Feminism . . . . . . . . . . . . . Wintermute Each new member joining the Fellowship of Religious Humanists will receive, free, an issue containing one of the above-mentioned articles. Please specify which one you would like to receive. Mail your check or money order, with the form below, to: F.R.H., P.O. Box 278, Yellow Springs, Ohio 45387.

\begin{tabular}{|c|c|c|}
\hline $\begin{array}{l}\text { Membership* and Subscription } \\
\text { Subscription Only } \\
\text { Foreign: add } \$ 4 / \text { year postage }\end{array}$ & $\begin{array}{l}\square \text { One Year } \$ 25.00 \\
\square \text { One Year } \$ 15.00\end{array}$ & $\begin{array}{l}\square \text { Two Years } \$ 40.00 \\
\square \text { Two Years } \$ 25.00\end{array}$ \\
\hline \multicolumn{3}{|l|}{ name } \\
\hline \multicolumn{3}{|l|}{ address } \\
\hline city & state & zip \\
\hline
\end{tabular}

"Full rights of membership also include the newsletter, THE COMMUNICATOR. 


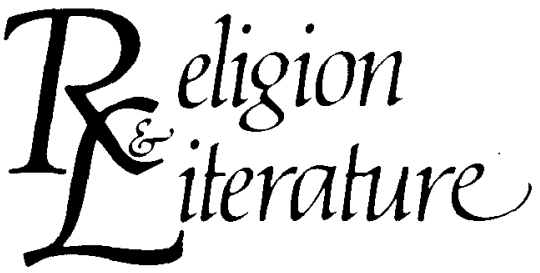

$R E L L$ is the forum for discussion of the relations between two crucial human concerns, the religious impulse and the literary forms of any era, place, or language.

We publish three times a year: scholarly articles, review essays, and book notices. Each year one special issue is devoted to a single theme or area:

1984: An investigation of sacred experience and word in Jewish traditions, edited by Elie Wiesel.

1985: The role of language, literature and the imagination in the life and writings of Simone Weil.

1988: The literature of Islam.

1990: Religious Thought and Contemporary

Literary Theory

1991: Spirituality in Women's Literature

$R \mathcal{E} L$ has published work by:

$\begin{array}{ll}\text { M.H. Abrams } & \text { Stanley Hauerwas } \\ \text { Thomas J.J. Altizer } & \text { Hugh Kenner } \\ \text { Felicia Bonaparte } & \text { Joseph Mazzeo } \\ \text { Robert MacAfee Brown } & \text { Sallie McFague } \\ \text { Donald Davie } & \text { Walter J. Ong } \\ \text { Robert Detweiler } & \text { Chaim Potok }\end{array}$

Louis Dupré Annemarie Schimmel

- and many other thinkers concerned with the intersection between language and the ineffable.

\section{Religion and Literature \\ Department of English \\ University of Notre Dame \\ Notre Dame, IN 46556}

Name

Address
Individual Rates:

1 Year: $\$ 20.00$

2 Years: $\$ 34.00$

For library rates, please inquire 


\section{JOIN US...}

in searching for the

connections between

current issues and

ultimate questions

subscribe now to
Aurobindo - Barbour - Berry - Boff Buber - Boulding • Bruteau - Cox Coles - conc - Fllul - Fackenhcim Freire - Schuissler-Finenza - Cintierrez Hassan - Ievinas - Ievertov - Ioncrgan McFague - Marty - Niebuhr • Panikkar Pelikan - Rahner - Ricocur - Ruether Soclle - Steiner - Tracy - Igolnik Waskow - Weil - West - Wiesel Wuthnow - Wyschogrod

\section{CROssCurrents}

a quarterly that for over 40 years bas been at the cutting edge of contemporary religious tbougbt.

Now published by the Association for Religion and Intellectual Life (ARIL), and explicitly committed to an interreligious perspective, CROSS CURRENTS is essential reading for those who know that pluralism is an inescapable datum of the world we live in.

\section{FRESH THINKING ON}

varieties of religious feminism

the crisis in the university ecology and world religions

Black and Third World theology

the Bible and the intellectual life

what it means to be a Moslem today

how to think about God after the Holocaust

\section{CROSSCurrents}

College of New Rochelle, New Rochelle, NY 10805-2308

NAME

ADDRESS

CITY STATE ZIP

$\square$ ENTER MY SLIRSCRIPTION (\$25.00 A YEAR, 4 ISSUES)

$\square$ CHECK FNCLOSEI $\square$ BILL ME 


\section{Journal of American Studies}

\section{Aims and Scope}

This well-established interational journal is devoted to the pursuit of American studies by crossing traditional disciplinary barriers. It aims to create a genuine forum for the exchange of ideas, welcoming articles from a wide range of fields and from scholars of various nationalities.

The Journal covers...

- literature "history "institutions -economics "politics "social studies 'geography 'arts -architecture popular culture - film -drama "music

And encourages...

Cross-disciplinary approaches and comparative studies of American and other cultures.

\section{Special Issue}

The December 1991 issue, representing the completion of the first 25 years of the journal, is a special issue devoted to American Ethnicity.

\section{Reviews}

The Journal contains an extensive book review section and publishes review essays.

And to keep you in touch with research in progress...

A list of theses on American topics in progress and recently completed at British Universities is included biennially.

Subscription Information: Journal of American Studies costs $£ 49$ (1991)/ $£ 53$ (1992). EAAS members: $£ 25$ (1991)/ $£ 27(1992)$.

Please send me further information on Journal of American Studies

Name Address

Send to: Journals Marketing Department, Cambridge University Press, FREEPOST*, The Edinburgh Building, Cambridge CB2 1BR, England TEL: (0223) 325806 or FAX (0223) 315052 (* no postage stamp necessary if posted in UK) In US \& Canada, write to Cambridge University Press, 40 West 20th Street, New York, NY 10011-4211, USA 


\section{American Studies from Cambridge}

\section{Journal of \\ Prospects}

American

\section{Studies}

Editor: MICHAEL HEALE, Lancaster University

Associate Editor: RICHARD GRAY, University of Essex

Journal of American Studies publishes work by scholars from all over the world on American literature, history, politics, economics, geography and related subjects. A 'Notes \& Comments' provides a forum for shorter pieces and responses from readers in reply to articles and reviews. Also included is an invaluable book reviews section and review essays on groups of titles.

Volume 27 in 1993, published in April, August and December. f56; f29 for members of EAAS; $\mathbf{2 4}$ for members of BAAS paid through Association. ISSN 0021-8758

\section{Take a closer look!}

Please send me further information about $\square$ Prospects $\square$ Journal of American Studies

Name

Address
Editor: JACK SALZMANN, Center for American Cultural Studies, Columbia University

Prospects is a multi-disciplinary journal that explores all aspects of American civilisation. It has as its prime concern the presentation of exceptional works of criticism and scholarship that elucidate the essential nature of the American character. Articles combine sound, creative scholarship with speculative discourse. Prospects publishes challenging and stimulating theoretical essays in interdisciplinary subject areas ranging over literature, film, humour, satire, photography, music, history, art, urban studies, television and sociology.

Volume 18 in 1993, published in October. $\$ 45$ for institutions; $£ 26$ for individuals; $\mathbf{f 2 1}$ for members of EAAS and BAAS. ISSN 0351-2333

Send to: Journals Marketing Dept, Cambridge University Press, FREEPOST ${ }^{*}$, The Edinburgh Building, Cambridge CB2 IBR, UK.

Tel: +44 (0)223325806 Fax: +44 (0)223315052 ( ${ }^{*}$ no postage stamp necessary if posted in UK) In USA, Canada \& Mexico write to: Cambridge University Press, 40 West 20th Street, New York, NY IOOII-4211, USA

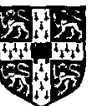
UNIVERSITY PRESS 
